\title{
PUBLICATION TRENDS ON HALAL TOURISM: A BIBLIOMETRIC REVIEW
}

\author{
KHAIRUL HAFEZAD ABDULLAH \\ Science Laboratory Unit, Department of Academic Affairs, Universiti Teknologi MARA, \\ Arau Campus, 02600 Arau, Perlis, Malaysia. \\ SAS Young Research Fellow Member, Scholars Academic and Scientific Society, 204 \\ Borhawor, Murajhar Hojai, Assam, India. \\ Corresponding author: khairul085@uitm.edu.my
}

(Received: 18 ${ }^{\text {th. }}$ Feb. 2021, Accepted: $15^{\text {th }}$ Jun. 2021, Published on-line: 26 ${ }^{\text {th }}$ Jul. 2021)

\begin{abstract}
Halal tourism has grown in popularity due to the rise of the Muslim population; howbeit it is still a relatively new field. This study aimed to evaluate halal tourism's publication trends, research areas, prolific sources, most cited documents, co-authorship concerning authors, institutions and countries, and keywords co-occurrence. Using the Scopus database, 118 halal tourism publications were disseminated between 2010 and 2020. This study found an increase in halal tourism in 2018, and the rate increased to 42 in 2020. It can be construed that halal tourism draws in a variety of research areas. Indonesian scholars have been contributed to $26.42 \%$ of the overall publications, which leading 34 other countries. Authors' keywords of 'Islamic tourism', 'Muslim tourists', 'halal hospitality', 'customer satisfaction', 'halal certification' and 'religiosity' have substantially impacted the online search for information. This bibliometric study offers a comprehensive and in-depth glance at halal tourism, which could aid industry and academia.
\end{abstract}

KEYWORDS: Halal tourism; Publication trends; Graphical visualisations; Scopus database; Muslim Tourists

\section{INTRODUCTION}

Since the turn of the $21^{\text {st }}$ century, the tourism industry has grown around $10 \%$ of the world's gross domestic product (GDP) with an estimated \$ 1,340 billion in tourism receipts and roughly 13,260 billion international tourist arrivals worldwide, (Dogru, Suess, \& Sirakaya-Turk, 2020). Mastercard and Crescentrating (2018) reported that the tourism industry would contribute $\$ 180$ billion to $\$ 300$ billion to the global economy over the next few decades. Thus, it is shown that the tourism industry becomes the most crucial sector to enhance its economic growth. The tourism industry is also reliant on an increase in the population of the world. The Muslim population accounts for about $30 \%$ of the world's population and is projected to continue to grow, (Shafaei \& 
Mohamed, 2015). Muslim tourists have increased by almost 30\% in 2016, which is expected to increase in the coming years, (Kamin, 2019). Therefore, halal tourism plays an essential role in providing quality and halal services to attract more Muslim visitors, (Mohsin, Ramli, \& Alkhulayfi, 2016).

Halal tourism has increased in popularity over the past several decades and constitutes USD 180 billion annual economic contributions, which is anticipated to rise about USD 300 billion in 2020, (Al-Ansi et al., 2020; Han et al., 2021). By taking advantage of halal tourism, a business will stay competitive and increase its customer base, (Kim, Im, \& King, 2015). Singapore, South Africa, Thailand, United Kingdom, Bosnia and Herzegovina, India, Germany, Australia, and Tanzania are among the top ten non-Islamic countries that fascinate Muslim visitors, (Mastercard \& Crescentrating, 2018). Besides, the COMCEC Coordination Office (2016) reported that Islamic countries such as Malaysia, United Arab Emirates, Turkey, Indonesia, Saudi Arabia, Morocco, Jordan, Qatar, Tunisia, and Egypt are the largest visit countries for Muslims. Halal tourism should be based on Islamic law because every Muslim must travel to meet Islamic Shariah's requirements to perform Hajj and Umrah or travel to seek knowledge and medical treatment, (El-Gohary, 2016). At present, for example, in Lombok, Indonesia, there is no tourism infrastructure oriented toward halal tourism, which is utterly based on Islamic values, (Khoiriati, Krisnajaya, \& Dinarto, 2018).

Halal tourism is the act of Muslim travel in which products, leisure, recreation and social purposes fit Muslim teachings, (Oktadiana, Pearce, \& Chon, 2016). Halal tourism, also often referred to as Islamic tourism or Muslim tourism, aims to open new opportunities to enhance economic growth, (Azam, Abdullah, \& Razak, 2019). However, using halal tourism and Islamic tourism as the same term can be questioned, (Battour \& Ismail, 2016). Halal refers to any company producing or trading halal goods to ensure Halal integrity until the end-user, (Ali, Tan, \& Ismail 2017). Halal covers Islamic laws in various aspects, including consuming food and drink, running a business, work, and other leisure activities such as tourism. According to Islam's instructions and prohibitions, the essential requirement signified that halal became the mainstay in shaping Muslims' personalities. Muslims' attitudes and behavioural were also significant in tourism. The reason is that their decisions often rely on the precepts and obligations established in the Holy Quran. Islam is directly related to its beliefs and doctrines, such as Islamic law, Islamic values, principles and ideas, and Islamic worship, (Douglass \& Shaikh, 2004). According to El-Gohary (2016), the regulations and guidelines found in Islamic law impact tourism services by demanding a commitment to their clarification. However, regardless of religious studies' importance, halal tourism is still underrepresented in the literature. It is distressing to find that little is accredited about halal tourism, (El-Gohary, 2016).

Halal tourism is vital because Muslim travellers' unfavourable tourism experience in a nonIslamic country is quite common due to a lack of understanding of Muslim culture, Islamic hospitality, and Islam's principles, (Al-Ansi et al., 2020; Han et al., 2019). The Muslim travel market will be the fastest-growing segment worldwide and potentially attractive to specific niche markets, (Yousaf \& Xiucheng, 2018). Although the field is growing, it is still a young and underdeveloped scholarly area, (Vargas-Sánchez \& Moral-Moral, 2019). Therefore, it is necessary to promote academic studies on halal tourism to contribute to the knowledge needed to help practitioners adapt tourism services to this attractive segment's needs and desires. The current research's fundamental purpose was to establish halal tourism-focused publication patterns over the last ten years, (from 2010 to 2020). It is also to classify research areas, prolific sources, most cited documents, co-authorship analysis concerning authors, institutions, countries, and keywords co-occurrence analysis on halal tourism. The information provided in this study is envisioned to 
provide a concise overview of the future of halal tourism research that will allow readers, practitioners and researchers to obtain insight that benefits their studies. The approach to this bibliometric review could lead to substantial contributions to current halal tourism research.

\section{MATERIALS AND METHODS}

A bibliometric analysis is a means to understand the nature of research in a particular domain based on the extant literature. This type of approach separates the bibliometrics from the review paper, which was predominantly projected to address the most recent developments and possible directions for a specific subject which the authors discussed, (Ellegaard \& Wallin, 2015; Zupic \& C̆ater, 2015). In this study, the scholarly analysis was conducted to explore how halal tourism is employed, used or applied.

The bibliometric data is created on the publications' countries and languages, the annual number of publications, journals and authors' prominence, and the critical research areas. A bibliometric analysis was conducted using several databases such as Web of Science (WoS), Scopus, and Google Scholar. The Scopus database was used for this study so that data on halal tourism could be obtained. The Scopus database contains the most critical, most significant and most cited researchers in research. The database also includes over 16,000 journals, trade papers, conference proceedings, and patents, which provide a broad range for researching various academic, medical and social subjects, (Khudzari et al., 2018; Sweileh, 2020).

Bibliometric data was retrieved on January 21, 2021, to identify precise keywords and appropriate information in line with a specific objective that has been decided. The keyword of 'Halal Tourism' based on the TITLE-ABS-KEY and quotation marks was customed to generate accurate search results. The retrieved data yielded 118 publications from 2010, where the article related to 'Halal Tourism' began to be recorded in the Scopus database until 2020. Out of 118 publications, 105 were articles from various journal sources, eight were books, and five were conference papers. A total of 117 publications were written in English and one article was written in Spanish. The data, which is in Comma-separated Values (CSV) and Research Information Systems (RIS) such as years, authors, the field of study, article sources, countries, and languages were exported to Microsoft Excel, Publish or Perish (PoP), and VOSviewer software for further analysis.

\section{RESULTS AND DISCUSSION}

\subsection{Publication Trends}

Figure 1 shows that a total of 118 articles have been written within ten years. However, only 24 out of 118 publications were considered open access, suggesting that most of these publications are not publicly available. The user needs to pay for access to the information. It is therefore recommended that articles be written in open access to obtain more citations. The first publication dated back to 2010, and no records were found for 2012 and 2013. The findings suggest that halal tourism's intense interest began in 2018 when more than 20 articles were found. From 2010 to 2015, publications have been sluggish, with less than five articles published annually. However, the number of publications increased by 11 in 2016 and dropped to nine in 2017. The number of publications increased exponentially by 42 in 2020 . This could be since Muslim travellers were a new market segment with specific needs and were looking for destinations with unique and 
different experiences, (Meirezaldi, 2020). Also, halal tourism is a part of the Muslim tourism industry that strictly complies with Islamic Shariah teachings, which have received increased attention in Muslim and non-Muslim regions, (Rasul, 2019). Furthermore, the number of worldwide researchers and the continued increase of halal tourism led to growing publications. Due to the observed exponential growth in halal tourism in 2018-2020, it can be concluded that this academic field is justifiable and relevant.

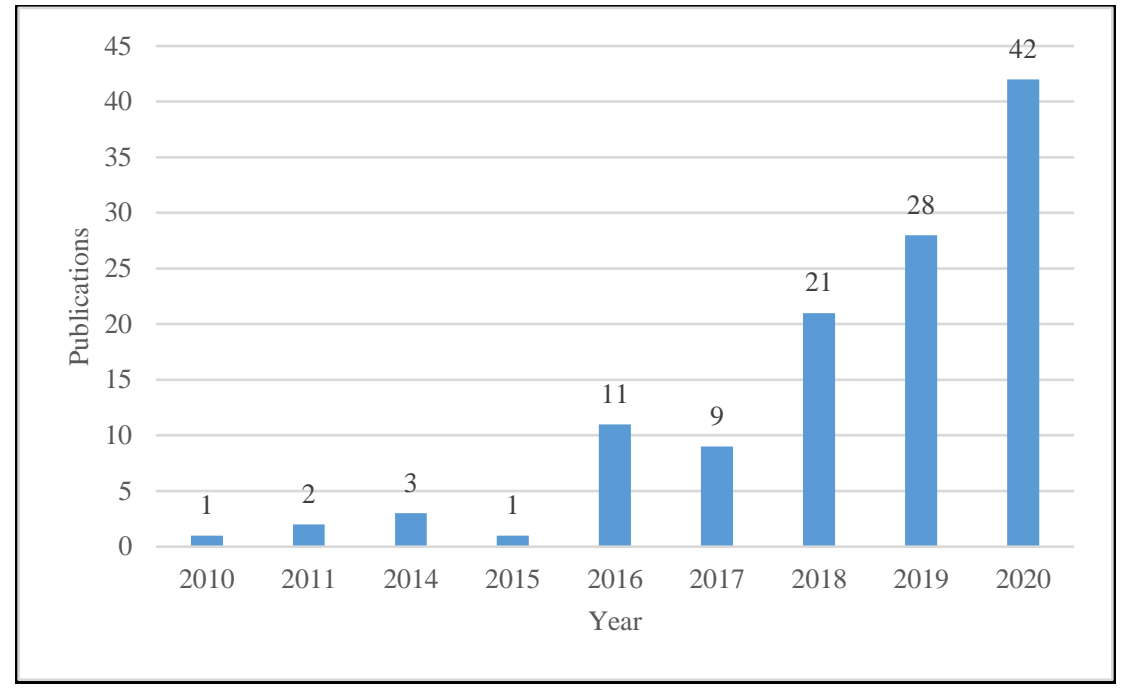

Figure 1: Publication trends in halal tourism.

\subsection{Analysis of Research Areas}

Halal tourism is a growing industry with various research groups working on this topic. As shown in Table 1, Business, Management and Accounting are the main focus of halal tourism. This finding is probable as this review focuses on the halal tourism concept, its business process, and the tourism industry's challenges, (Junaidi, 2020). This aspect analyses the theoretical issues that will be affected by halal tourism and how it will influence a customer's satisfaction, (Abror et al., 2019). Another field of study is Social Science, with 41 publications and Economics, Econometrics and Finance, with 16 publications. The findings indicated that halal tourism is becoming a foundation of Islamic law. The countries in South East Asia are diverse in their cultures, religions, and customs, and most of the population are Muslim, thus affecting policymaking, (Nurdiansyah, 2018). One of the keys to the economy is trade and tourism, which prioritise each country's tourist regions to attract tourists to visit the country. As a result, tourism improves the development of a nation and increases foreign exchange and income. 
Table 1: Top Five Research area in Halal Tourism.

\begin{tabular}{clc}
\hline Rank & \multicolumn{1}{c}{ Research Area } & Publications \\
\hline $\mathbf{1}$ & $\begin{array}{l}\text { Business, Management and } \\
\text { Accounting }\end{array}$ & 83 \\
\hline $\mathbf{2}$ & Social Sciences & 41 \\
\hline $\mathbf{3}$ & $\begin{array}{l}\text { Economics, Econometrics } \\
\text { and Finance }\end{array}$ & 16 \\
\hline $\mathbf{4}$ & Environmental Science & 13 \\
\hline $\mathbf{5}$ & Arts and Humanities & 9 \\
\hline $\mathbf{5}$ & Computer Science & 9 \\
\hline
\end{tabular}

\subsection{Prolific Sources}

To identify the most influential source titles in halal tourism, Table 2 presents a list of the prolific source titles with at least three publications. Considering the number of publications, the Journal of Islamic Marketing seems to be the most influential source title in this field, with 18 publications. Other relevant sources are the Tourism Management Perspectives in the second rank and the Journal of Environmental Management and Tourism and Malaysian Journal of Consumer and Family Economics at the third rank. Based on this finding, it is suggested that the publications have been contributing useful knowledge that will allow prospective practitioners and researchers to refer to and be beneficial for their future research on halal tourism.

Table 2: The Prolific Source Titles with at least Three Publications.

\begin{tabular}{clc}
\hline Rank & \multicolumn{1}{c}{ Sources } & Publications \\
\hline $\mathbf{1}$ & Journal of Islamic Marketing & 18 \\
\hline $\mathbf{2}$ & Tourism Management Perspectives & 11 \\
\hline $\mathbf{3}$ & $\begin{array}{l}\text { Journal of Environmental Management and } \\
\text { Tourism }\end{array}$ & 4 \\
\hline $\mathbf{3}$ & $\begin{array}{l}\text { Malaysian Journal of Consumer and Family } \\
\text { Economics }\end{array}$ & 4 \\
$\mathbf{4}$ & Asia Pacific Journal of Tourism Research & 3 \\
\hline $\mathbf{4}$ & Geojournal Of Tourism and Geosites & 3 \\
\hline $\mathbf{4}$ & Journal of Destination Marketing and Management & 3 \\
\hline $\mathbf{4}$ & Sustainability Switzerland & 3 \\
\hline
\end{tabular}

\subsection{Most Cited Documents}

The next step is to recognise the most active and successful authors in the field of halal tourism. A list of the ten most-cited documents is provided in Table 3. The number of citations is generally seen as a fair representation of the popularity and influence of work among the scientific community, (Merigó \& Yang, 2017). As indicated in Table 3, the 2016 paper written by M. Battour and M.N. Ismail was listed as the most-cited work, with 107 citations and 21.4 cites per year for the article entitled 'Halal tourism: Concepts, practises, challenges and future' published by the 
Tourism Management Perspectives. Next was H. El-Gohary's work in 2016, released by Tourism Management Perspectives, with 68 citations and 13.6 cites per year for an article entitled ' $H a l a l$ tourism, is it really Halal?'. This article shares a similar citation ranking with an article written by M.M. Battour, M.N. Ismail, and M. Battor in 2010 entitled 'Toward a halal tourism market' published by Tourism Analysis. Nevertheless, regarding cites per year, the paper written by M.M. Battour, M.N. Ismail, and M. Battor obtained a smaller number of cites per year with 6.18. The most cited article per year is 28, written by H. Han, A. Al-Ansi, H.G.T. and Olya, W. Kim in 2019 entitled 'Exploring halal-friendly destination attributes in South Korea: Perceptions and behaviours of Muslim travellers toward a non-Muslim destination', published by Tourism Management.

Table 3: The Top Ten Most Cited-documents on Halal Tourism.

\begin{tabular}{|c|c|c|c|c|c|}
\hline Cites & $\begin{array}{c}\text { Cites Per } \\
\text { Year }\end{array}$ & Authors & Year & Title & Source \\
\hline 107 & 21.4 & $\begin{array}{l}\text { M. Battour, } \\
\text { M.N. Ismail }\end{array}$ & 2016 & $\begin{array}{l}\text { Halal tourism: Concepts, } \\
\text { practises, challenges and } \\
\text { future }\end{array}$ & $\begin{array}{l}\text { Tourism } \\
\text { Management } \\
\text { Perspectives }\end{array}$ \\
\hline 68 & 13.6 & H. El-Gohary & 2016 & $\begin{array}{l}\text { Halal tourism, is it really } \\
\text { Halal? }\end{array}$ & $\begin{array}{l}\text { Tourism } \\
\text { Management } \\
\text { Perspectives }\end{array}$ \\
\hline 68 & 6.18 & $\begin{array}{l}\text { M.M. } \\
\text { Battour, M.N. } \\
\text { Ismail, M. } \\
\text { Battor }\end{array}$ & 2010 & $\begin{array}{l}\text { Toward a halal tourism } \\
\text { market }\end{array}$ & $\begin{array}{l}\text { Tourism } \\
\text { Analysis }\end{array}$ \\
\hline 67 & 13.4 & $\begin{array}{l}\text { A. Mohsin, N. } \\
\text { Ramli, B.A. } \\
\text { Alkhulayfi }\end{array}$ & 2016 & $\begin{array}{l}\text { Halal tourism: Emerging } \\
\text { opportunities }\end{array}$ & $\begin{array}{l}\text { Tourism } \\
\text { Management } \\
\text { Perspectives }\end{array}$ \\
\hline 52 & 10.4 & $\begin{array}{l}\text { J.C. } \\
\text { Henderson }\end{array}$ & 2016 & $\begin{array}{l}\text { Halal food, certification } \\
\text { and halal tourism: Insights } \\
\text { from Malaysia and } \\
\text { Singapore }\end{array}$ & $\begin{array}{l}\text { Tourism } \\
\text { Management } \\
\text { Perspectives }\end{array}$ \\
\hline 46 & 23 & $\begin{array}{l}\text { H. Han, A. } \\
\text { Al-Ansi, } \\
\text { H.G.T. Olya, } \\
\text { W. Kim }\end{array}$ & 2019 & $\begin{array}{l}\text { Exploring halal-friendly } \\
\text { destination attributes in } \\
\text { South Korea: Perceptions } \\
\text { and behaviours of Muslim } \\
\text { travellers toward a non- } \\
\text { Muslim destination }\end{array}$ & $\begin{array}{l}\text { Tourism } \\
\text { Management }\end{array}$ \\
\hline 41 & 8.2 & $\begin{array}{l}\text { S. Razzaq, } \\
\text { C.M. Hall, G. } \\
\text { Prayag }\end{array}$ & 2016 & $\begin{array}{l}\text { The capacity of New } \\
\text { Zealand to accommodate } \\
\text { the halal tourism market - } \\
\text { Or not }\end{array}$ & $\begin{array}{l}\text { Tourism } \\
\text { Management } \\
\text { Perspectives }\end{array}$ \\
\hline 38 & 7.6 & $\begin{array}{lr}\text { Z. } & \text { Samori, } \\
\text { N.Z. } & \text { Md } \\
\text { Salleh, M.M. } \\
\text { Khalid }\end{array}$ & 2016 & $\begin{array}{l}\text { Current trends on Halal } \\
\text { tourism: Cases on selected } \\
\text { Asian countries }\end{array}$ & $\begin{array}{l}\text { Tourism } \\
\text { Management } \\
\text { Perspectives }\end{array}$ \\
\hline
\end{tabular}




\begin{tabular}{lllll}
\hline 36 & 7.2 & $\begin{array}{l}\text { H. Oktadiana, 2016 } \\
\text { P.L. Pearce, } \\
\text { K. Chon }\end{array}$ & $\begin{array}{l}\text { Muslim travellers' needs: } \\
\text { What don't we know? }\end{array}$ & $\begin{array}{l}\text { Tourism } \\
\text { Management } \\
\text { Perspectives }\end{array}$ \\
\hline 35 & 11.67 & $\begin{array}{l}\text { S. Yousaf, F. 2018 } \\
\text { Xiucheng }\end{array}$ & & $\begin{array}{l}\text { Halal culinary and tourism } \\
\text { marketing strategies on } \\
\text { government websites: A } \\
\text { preliminary analysis }\end{array}$ \\
& & &
\end{tabular}

The determination of the most influential authors in the field is another crucial aspect of the bibliometric analysis. Table 4 shows seven different authors with at least seven articles related to halal tourism. Al-Ansi, A. and Han, H. were at the top of the list with five publications, followed by Abror, A., Battour, M., and Ramli, N. with three articles. It is noteworthy that authors from Indonesia associated with Universitas Negeri Padang have been the most active authors to publish halal tourism research over the last ten years. The reason for this is that halal tourism has grown in Indonesia in recent years and fueled Indonesia's economic growth, although the world economy has slowed down, (Jaelani, 2017). Besides, halal tourism in Indonesia has become a rising trend to court the Muslim tourist community, (Winarti, 2017). Thus, it is disclosed that halal tourism studies had been conducted to understand the demands and needs of Muslim visitors by Indonesian scholars.

Table 4: The Status of Authors with at least Three Publications.

\begin{tabular}{lccll}
\hline \multicolumn{1}{c}{ Authors } & Publications & H-index & \multicolumn{1}{c}{ Affiliation } & Country \\
\hline Al-Ansi, A. & 5 & 6 & Sejong University, Seoul & South Korea \\
\hline Han, H. & 5 & 50 & Sejong University, Seoul & South Korea \\
\hline Abror, A. & 3 & 4 & Universitas Negeri Padang & Indonesia \\
\hline Battour, M. & 3 & 12 & University of Tanta & Egypt \\
\hline Ramli, N. & 3 & 3 & $\begin{array}{l}\text { International Islamic University of } \\
\text { Malaysia }\end{array}$ & Malaysia \\
\hline Trinanda, O. & 3 & 2 & Universitas Negeri Padang & Indonesia \\
\hline Wardi, Y. & 3 & 3 & Universitas Negeri Padang & Indonesia \\
\hline
\end{tabular}

\subsection{Authors Co-authorship Analysis}

Collaborative publications have the most significant recognition and scientific impact, together with inter-institutional collaborative articles, single-country articles and single-author articles, (Wambu \& Ho, 2016). The most popular form of collaborative network is known as co-authorship. The network visualisation of co-authors in halal tourism is shown in Figure 2. Each circle refers to the author, and the number of publications is the size of the circle. The link between the two circles (nodes) stands for the cooperative relationship between the two authors, and the breadth of the link (lines) reflects the strength of the partnership. Authors with a minimum of a publication are visualised in Figure 2 using a network visualisation. Out of the 296 authors who have conducted the research, 13 authors reached the thresholds and were related. The circles denoting authors in the same cluster suggested they work in a related area and collaborate closely. As shown in Figure 2, there are four clusters. The first cluster is denoted in blue colour represented three 
authors. The second cluster, which is yellow, consists of two authors, the third cluster, which is red colour yielded four authors, and the fourth cluster, which is green, comprises four authors.

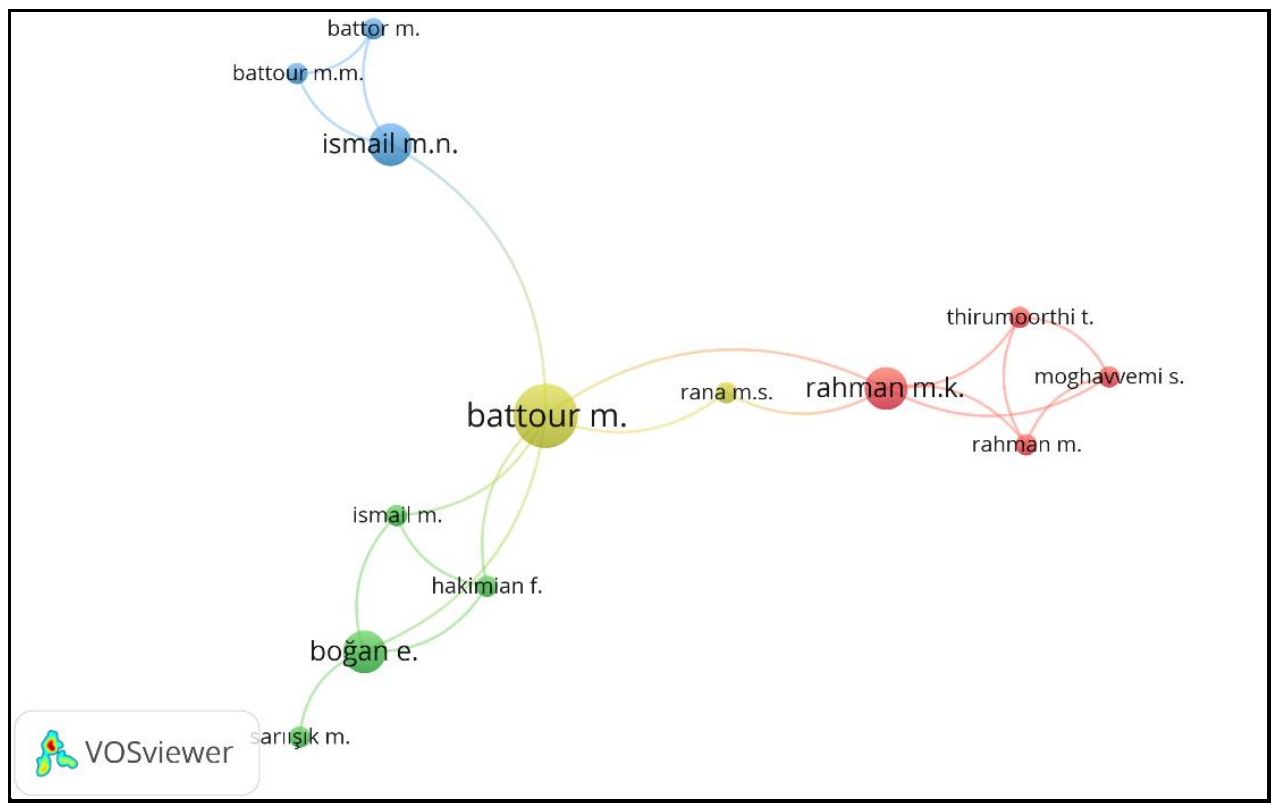

Figure 2: Network of authors co-authorship.

\subsection{Institutions Co-authorship Analysis}

Co-authorship institutions' study represents the degree of contact between institutions and prominent research institutions, (Reyes Gonzalez, Gonzalez Brambila \& Veloso 2016). The institutions' contribution was estimated by the affiliation institute of at least one author of the written articles, and 226 institutions have been selected. Figure 3 presents the network of institutions performing a co-authorship analysis of 6 institutions in two clusters.

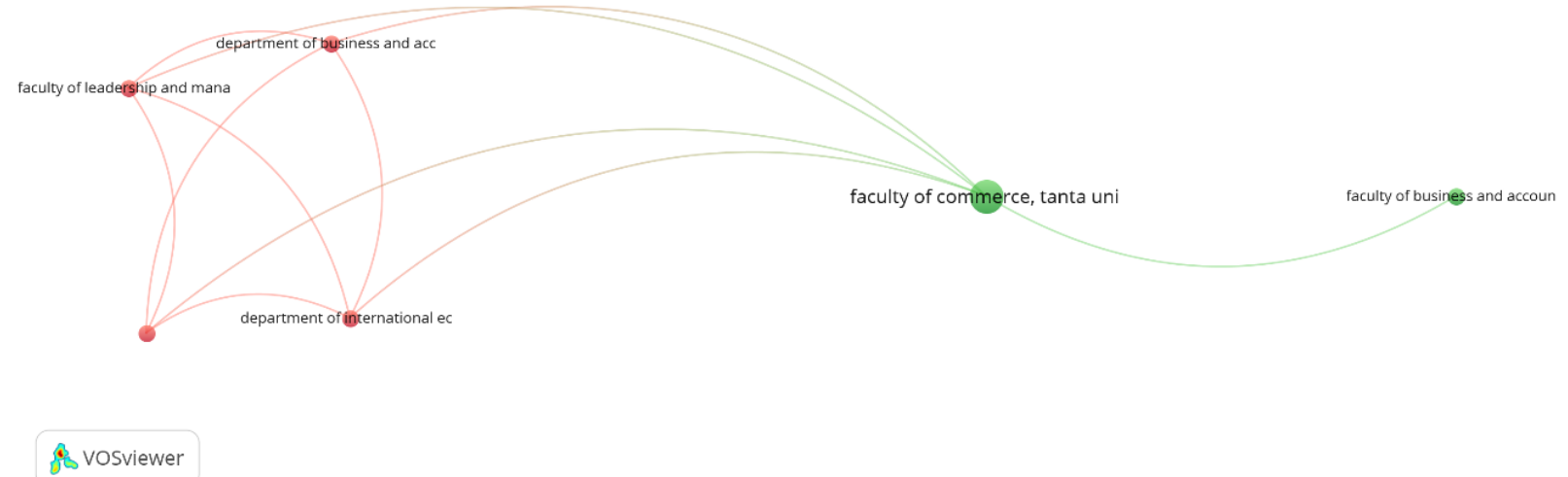

Figure 3: Network of institutions co-authorship. 


\subsection{Countries Co-authorship Analysis}

A network analysis was carried out to classify the countries of authors who have contributed to halal tourism. As shown in Figure 4, the co-authorship network consists of nine countries and is divided into three clusters. The nodes represent the countries, where the more extensive the nodes indicate a more significant number of publications. In this scenario, Indonesia had more significant nodes. It has been revealed that Indonesia has a considerable volume of publications (42 publications). The second rank goes to Malaysia with 29 publications, and Spain was in the third rank with eight publications. Co-authorship analyses have shown that Indonesia has become a focal point and has cooperated closely with several countries such as Australia, New Zealand, Spain, and Malaysia. It is demonstrated that there are increasing international exchanges that encouraged academic cooperation and played an essential role in improving scientific interaction in halal tourism. The most productive ten countries of the network are shown in Table 5.

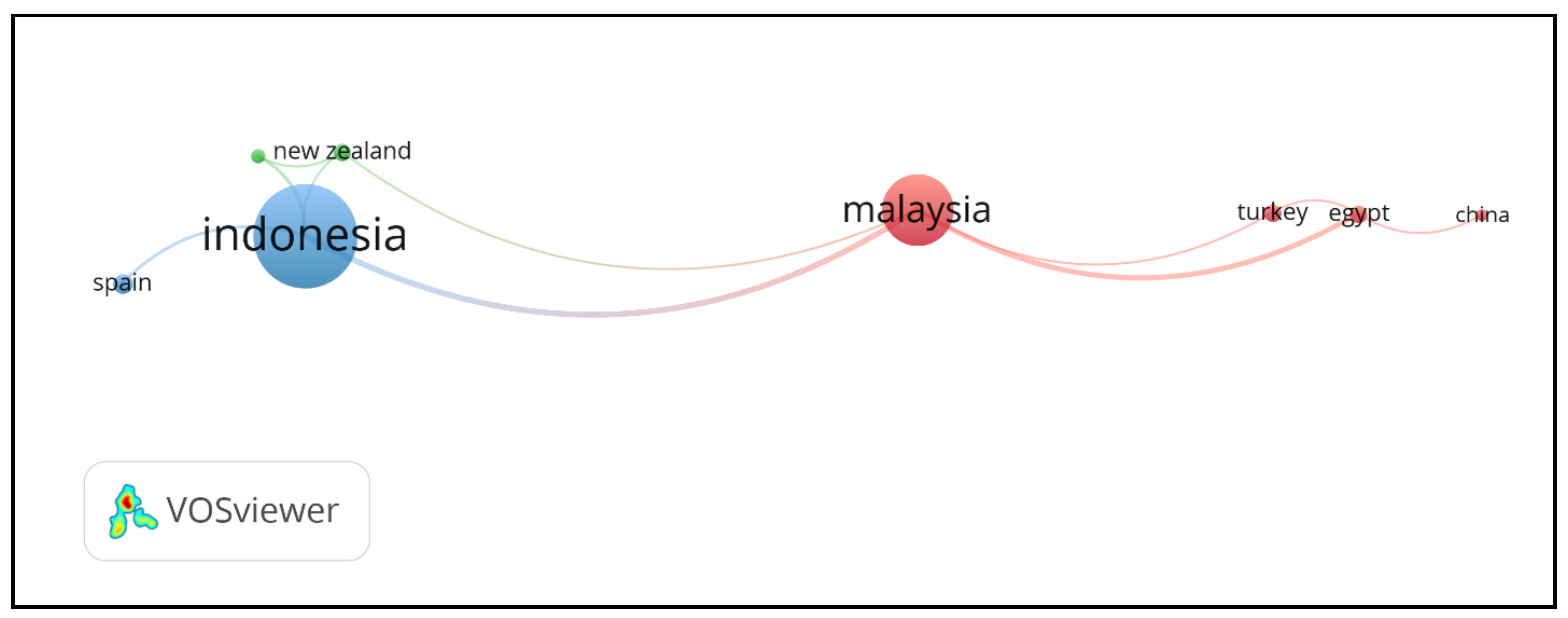

Figure 4: Network of countries co-authorship.

Table 5: The Status of Countries with at least Five Publications.

\begin{tabular}{|l|c|c|}
\hline \multicolumn{1}{|c|}{ Country } & Publications & $\begin{array}{c}\text { Percentage } \\
(\mathbf{\%})\end{array}$ \\
\hline Indonesia & 42 & 26.42 \\
\hline Malaysia & 29 & 18.24 \\
\hline Spain & 8 & 5.03 \\
\hline Egypt & 7 & 4.40 \\
\hline New Zealand & 7 & 4.40 \\
\hline Turkey & 7 & 4.40 \\
\hline Australia & 6 & 3.77 \\
\hline China & 5 & 3.14 \\
\hline South Korea & 5 & 3.14 \\
\hline
\end{tabular}




\subsection{Keywords Co-occurrence Analysis}

This section provides a visual description to deepen the conclusions of the authors' cooccurrence keywords. VOS viewer also enables the most common keywords in a particular series of publications to analyse the author's keywords. Figure 6 provides a network diagram of the author's keywords in which various colours, node sizes, font sizes, and the thickness of the connecting lines illustrate the relationship with other keywords, (Sweileh et al., 2017). Keywords that appeared more than five times, with 346 keywords, were included in the map. VOSviewer divided the keywords into four main clusters that represent 13 authors' keywords. The most famous keywords are the critical term 'halal tourism' in blue nodes. In addition, some common keywords are 'Islamic tourism', 'Muslim tourists', 'halal hospitality', 'customer satisfaction', 'halal certification' and 'religiosity' in terms of their coincidences. The results confirm that halal tourism research has a cross-disciplinary perspective and links various fields, including business and management and social sciences.

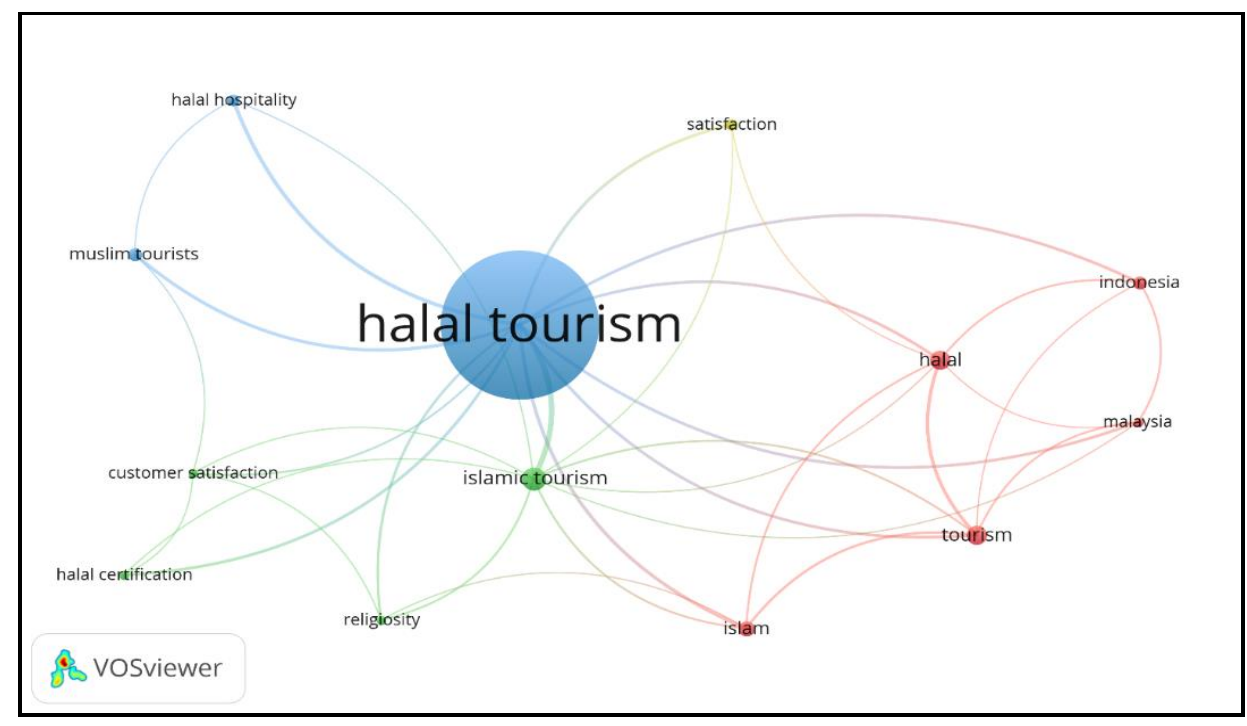

Figure 5: Network visualisation map of authors' keywords.

\section{CONCLUSION}

In conclusion, this bibliometric analysis promotes examining and integrating established directions toward halal tourism and emerging trends. Based on a bibliometric analysis of 10 years of publication trends, the study found that the information below will be able to provide practitioners and researchers with the related facts:

a) The number of halal tourism publications increased exponentially in 2018, with hike publications by 42 in 2020 .

b) The research areas 'Business, Management and Accounting' became the most research hotspots in halal tourism, with 83 publications.

c) The Journal of Islamic Marketing seems to be the most influential source title on halal tourism, with 18 publications. 
d) The 2016 paper written by M. Battour and M.N. Ismail was the most cited publication, with 107 citations and 21.4 cites per year for the article entitled 'Halal tourism: Concepts, practises, challenges and future' published by the Tourism Management Perspectives. This article will be able to guide future researchers to comprehend better halal tourism concepts.

e) Co-authorship analyses have shown that Indonesia has been a focal point and has collaborated closely with other countries. It is designated that those growing foreign collaborations have facilitated academic collaboration and play an essential role in enhancing intellectual engagement in halal tourism research.

f) Research on halal tourism has an interdisciplinary perspective concerning the authors' keywords such as 'halal hospitality', 'customer satisfaction' and 'Muslim tourists', as it connects with a wide range of fields, including business and management, as well as social sciences.

The bibliometric analysis allows the art of a particular field or topic to be understood. Nevertheless, the methodology conducted and document categorisations cannot be disregarded. In this specific instance, the nature of a bibliometric analysis per se is therefore limited. Therefore, only publications that follow the search refinement ('halal tourism') set out in the methodology have been included. It is also essential to note that other vital databases, such as Google Scholar and Microsoft Academic, are also beneficial for conducting a bibliometric analysis.

Based on the bibliometric analysis, professionals and researchers will be best able to recognise the importance of examining or evaluating halal tourism in their future studies. The information provided in this study is envisioned to provide a concise overview of the future of halal tourism research to obtain insight that benefits the studies. In order to comprehend the in-depth on halal tourism, future analyses are suggested to scrutiny the elements of 'Islamic tourism', 'Muslim tourists', 'halal hospitality', 'customer satisfaction', 'halal certification' and 'religiosity' rigorously as these terms were closely connected and attract curiosity from previous studies.

\section{REFERENCES}

[1] Abror, A., Wardi, Y., Trinanda, O., \& Patrisia, D. (2019). The impact of Halal tourism, customer engagement on satisfaction: moderating effect of religiosity. Asia Pacific Journal of Tourism Research, 24(7), 633-643.

[2] Al-Ansi, A., Han, H., Kim, S., \& King, B. (2020). Inconvenient experiences among Muslim travellers: An analysis of the multiple causes. Journal of Travel Research, 1-19.

[3] Ali, M. H., Tan, K. H., \& Ismail, M. D. (2017). A supply chain integrity framework for halal food. British Food Journal, 119 (1), 20-38.

[4] Azam, M. S. E., Abdullah, M. A., \& Razak, D. A. (2019). Halal tourism: definition, justification, and scopes towards sustainable development. International Journal of Business, Economics and Law, 18(3), 23-31.

[5] Battour, M., \& Ismail, M. N. (2016). Halal tourism: Concepts, practises, challenges and future. Tourism management perspectives, 19, 150-154.

[6] COMCEC Coordination Office. (2016, February). Muslim friendly tourism: Understanding the demand and supply sides in the OIC member countries. Yücetepe Ankara, Turkey: Author. 
[7] Dogru, T., Suess, C., \& Sirakaya-Turk, E. (2020). Why do some countries prosper more in tourism than others? Global competitiveness of tourism development. Journal of Hospitality \& Tourism Research, 45(1), 215-256.

[8] Douglass, S. L., \& Shaikh, M. A. (2004). Defining Islamic education: Differentiation and applications. Current Issues in Comparative Education, 7(1), 5-18.

[9] El-Gohary, H. (2016). Halal tourism, is it really Halal? Tourism Management Perspectives, $19,124-130$.

[10] Ellegaard, O., \& Wallin, J. A. (2015). The bibliometric analysis of scholarly production: How great is the impact? Scientometrics, 105(3), 1809-1831.

[11] Han, H., Al-Ansi, A., Olya, H. G., \& Kim, W. (2019). Exploring halal-friendly destination attributes in South Korea: Perceptions and behaviours of Muslim travellers toward a nonMuslim destination. Tourism Management, 71, 151-164.

[12] Han, H., Lee, S., Ariza-Montes, A., Al-Ansi, A., Tariq, B., Vega-Muñoz, A., \& Park, S. H. (2021). Muslim travelers' inconvenient tourism experience and self-rated mental health at a non-Islamic country: Exploring gender and age differences. International Journal of Environmental Research and Public Health, 18(2), 1-17.

[13] Jaelani, A. (2017). Halal tourism industry in Indonesia: Potential and prospects. International Review of Management and Marketing, 7(3), 1-19.

[14] Junaidi, J. (2020). Halal-friendly tourism and factors influencing halal tourism. Management Science Letters, 10(8), 1755-1762.

[15] Kamin, D. (2019, January 18). The Rise of Halal Tourism. The New York Times. Retrieved from https://www.nytimes.com

[16] Khoiriati, S. D., Krisnajaya, I. M., \& Dinarto, D. (2018). Debating halal tourism between values and branding: A case study of Lombok, Indonesia. KnE Social Sciences, 494-515.

[17] Khudzari, J. M., Kurian, J., Tartakovsky, B., \& Raghavan, G. V. (2018). Bibliometric analysis of global research trends on microbial fuel cells using Scopus database. Biochemical Engineering Journal, 136, 51-60.

[18] Kim, S., Im, H. H., \& King, B. E. (2015). Muslim travellers in Asia: The destination preferences and brand perceptions of Malaysian tourists. Journal of Vacation Marketing, 21(1), 3-21.

[19] Mastercard \& Crescentrating. (2018, April). Global Muslim travel index 2018. Bukit Merah Central, Singapore: Mastercard \& Crescentrating Global Muslim Travel Index 2018.

[20] Meirezaldi, O. (2020). Halal tourism industry in Indonesia. Advances in Economics, Business and Management Research, 154, 126-129.

[21] Merigó, J. M., \& Yang, J. B. (2017). A bibliometric analysis of operations researches and management science. Omega, 73, 37-48.

[22] Mohsin, A., Ramli, N., \& Alkhulayfi, B. A. (2016). Halal tourism: Emerging opportunities. Tourism Management Perspectives, 19, 137-143.

[23] Nurdiansyah, A. (2018). Halal certification and its impact on tourism in Southeast Asia: a case study Halal tourism in Thailand. KnE Social Sciences, 26-43.

[24] Oktadiana, H., Pearce, P. L., \& Chon, K. (2016). Muslim travellers' needs: What don't we know? Tourism Management Perspectives, 20, 124-130.

[25] Rasul, T. (2019). The trends, opportunities and challenges of halal tourism: A systematic literature review. Tourism Recreation Research, 44(4), 434-450. 
[26] Reyes-Gonzalez, L., Gonzalez-Brambila, C. N., \& Veloso, F. (2016). Using co-authorship and citation analysis to identify research groups: a new way to assess performance. Scientometrics, 108(3), 1171-1191.

[27] Shafaei, F., \& Mohamed, B. (2015). Involvement and brand equity: a conceptual model for Muslim tourists. International Journal of Culture, Tourism and Hospitality Research, 9(1), 54-67.

[28] Sweileh, W. M. (2020). Bibliometric analysis of peer-reviewed literature on climate change and human health with an emphasis on infectious diseases. Globalisation and Health, 16, $1-17$.

[29] Sweileh, W. M., Shraim, N. Y., Al-Jabi, S. W., Sawalha, A. F., Rahhal, B., Khayyat, R. A., \& Sa'ed, H. Z. (2016). Assessing worldwide research activity on probiotics in paediatrics using Scopus database: 1994-2014. World Allergy Organization Journal, 9(1), 25.

[30] Vargas-Sánchez, A., \& Moral-Moral, M. (2019). Halal tourism: state of the art. Tourism Review, 74(3), 385-399.

[31] Wambu, E. W., \& Ho, Y. S. (2016). A bibliometric analysis of drinking water research in Africa. Water SA, 42(4), 612-620.

[32] Winarti, O. (2017). Halal Tourism in Indonesia: Does it attract only Muslim Tourists? Jurnal Studi Komunikasi, 1(3), 232-239.

[33] Yousaf, S., \& Xiucheng, F. (2018). Halal culinary and tourism marketing strategies on government websites: A preliminary analysis. Tourism Management, 68, 423-443.

[34] Zupic, I., \& Čater, T. (2015). Bibliometric methods in management and organisation. Organizational Research Methods, 18(3), 429-472. 